\title{
ASET
}

APPLIED SCIENCE AND ENGINEERING TECHNOLOGY

Keywords: Resistance Welding Solid-State Welding

Vessel Fabrication

Retention: Permanent

\section{UPSET WELDED 304L AND 316L VESSELS FOR STORAGE TESTS (U)}

\author{
by \\ W. R. Kanne, Jr. \\ W. R. Hanne, fe. \\ ISSUED: April 1966 \\ .3.
}


DOCUMENT: WSRC-TR-96-0087

TITLE: $\quad$ UPSET WELDED 304L AND 316L VESSELS FOR STORAGE TESTS (U)

APPROVALS MATERIALS TECHNOLOGY SECTION
S. L. West, TECHNICAL REVIEWER

DATE: May 7,1916

DATE:

D. T. Rankin, MANAGER
MATERIALS COMPATIBILITY \& JOINING GROUP MATERIALS TECHNOLOGY SECTION

T. L. Capeletti, MANAGER

DATE:

MATERIALS TECHNOLOGY SECTION 


\section{DISCLAIMER}

This report was prepared as an account of work sponsored by an agency of the United States Government. Neither the United States Government nor any agency thereof, nor any of their employees, makes any warranty, express or implied, or assumes any legal liability or responsibility for the accuracy, completeness, or usefulness of any information, apparatus, product, or process disclosed, or represents that its use would not infringe privately owned rights. Reference herein to any specific commercial product, process, or service by trade name, trademark, manufacturer, or otherwise does not necessarily constitute or imply its endorsement, recommendation, or favoring by the United States Government or any agency thereof. The views and opinions of authors expressed herein do not necessarily state or reflect those of the United States Government or any agency thereof. 

TABLE OF CONTENTS

Page No.

SUMMARY 1

INTRODUCTION 1

VESSEL DESIGN, MATERIAL, AND MACHINING 2

WELDING PROCEDURE DEVELOPMENT AND 3

VESSEL FABRICATION

QUALIFICATION OF VESSELS FOR STORAGE TESTING 4

LOADING AND STORAGE TESTING

CONCLUSIONS

ACKNOWLEDGMENTS

REFERENCES 6

TABLES

I. Status of F-Series Vessels 7

II. Test Results for 304L and 316L Vessels 8

FIGURES

1. Vessel Design 9

2. Electrode Design 10

3. Fixtures for Welding Vessels 11

4. Data Acquisition Trace 12

5. Fabrication of Vessels 13

6. Finished Vessel 14

7. Hydrostatic Pressure Tests 15

8. Pneumatic Pressure Tests 16

9. Metallographic Preparation of Vessels 17

10. Tube Attachment Weld 18

11. Metallographic Analysis of 304L Vessel F-13 19

12. Metallographic Analysis of 316L Vessel F-29 20

13. Hardness Traverse across Weld in 304L Vessel F-13 21

14. Hardness Traverse across Weld in 316L Vessel F-29 22

15. Plot of Hardness Data 23

16. Upset Welded Vessels 24 


\title{
UPSET WELDED 304L AND 316L VESSELS FOR STORAGE TESTS (U)
}

\author{
W. R. Kanne, Jr.
}

\section{SUMMARY}

Two sets of vessels for tritium storage tests were fabricated using upset welding. A solid-state resistance upset weld was used to join the two halves of each vessel at the girth. The vessels differ from production reservoirs in design, material, and fabrication process. One set was made from forged 304L stainless steel and the other from forged 316L stainless steel. Six vessels of each type were loaded with a tritium mix in November 1995 and placed in storage at $71^{\circ} \mathrm{C}$. This memo describes and documents the fabrication of the twelve vessels.

\section{INTRODUCTION}

Resistance upset welding is being evaluated as an improved process for fabrication of reservoirs. This welding process is attractive because it is reliable and employs equipment that is easy to operate, maintain, and control. Furthermore, the solidstate welds produced by this process have improved mechanical properties and metallurgical structure, compared to fusion welds. Integrity of the upset welding process has been previously demonstrated for several configurations by destructive and nondestructive testing, Ref. 1, 2 and 3.

Vessels fabricated by resistance upset welding are being placed in long-term tritium storage tests as a final demonstration of weld integrity. The storage tests are part of establishing the technical basis for the application. One set of upset welded vessels was placed in tritium storage in 1984 as an initial demonstration of tritium containment capability. Storage of these vessels has proceeded without incident. These vessels are cylindrical in shape and were made from bar stock 304L stainless steel. Two of these vessels were removed from storage after 5.5 years and destructively evaluated. No detrimental effects of the tritium storage were observed. Two of the cylindrical vessels were removed in 1995 and the remaining two are scheduled to be removed in 1996. Two sets of upset welded vessels fabricated from forged 21-6-9 stainless steel were placed in storage in October 1992. Storage has proceeded without incident for these 12 vessels. 
To complement the vessels previously placed in storage, vessels fabricated using resistance upset welding were made from forged 304L and 316L stainless steel. These two sets of vessels are the first forged 304L and 316L vessels fabricated for storage using resistance upset welding. This report clocuments the fabrication process and storage of the twelve vessels fabricated from forged $304 \mathrm{~L}$ and $316 \mathrm{~L}$ stainless steel using solid-state resistance upset welding.

\section{VESSEL DESIGN, MATERIAL, AND MACHINING}

Upset welded vessels, Figure 1A, were designed to minimize machining costs. The weld joint configuration of the two hemishells was designed to accommodate upset welding. The hemishells, Figure 1B, were machined at Savannah River. Tubes for the vessels were obtained from SRS production supply and were of 21-6-9 material. Capability for joining the 21-6-9 tubes to the 304L and 316L bodies was confirmed on test pieces prior to start of the program.

Material for the vessels was obtained from special forging runs at the Oxnard facility. Forgings were made to the specifications for Rocky Flats part no. 14837. Material specifications were P12044-F for 304L forgings and P32343-C for 316L forgings. Mechanical properties for the forgings, measured by Oxnard, were:

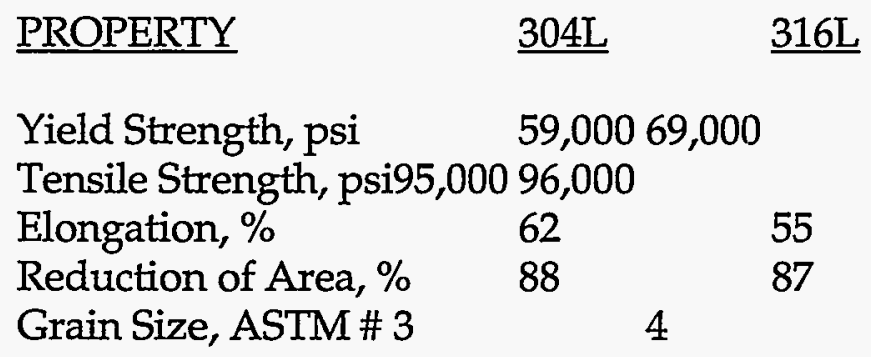

Hardness of the forged material was measured at the weld joint after machining of the shells. Hardness was RB-95 for the 304L forgings and RB-97 for the 316L forgings. The small difference in hardness indicated that the same upset welding procedure could be used for both materials.

Vessel hemishells were cleaned before welding using either the standard Nitradd cleaning process, Ref. 4, or an Oakite cleaning procedure, Ref. 5. The two procedures were used to accommodate a Los Alamos request that half of the vessels of each material be cleaned by the new Oakite process. The cleaning process used for each vessel is shown in Table I, along with a description of how each vessel was used.

Fixtures for the girth upset weld are shown in Figures 2 and 3. Electrodes carry the force and current to the weld joint area. A sleeve (drawing EES-22045-R2-004) positions the electrodes in vertical alignment. 
W. R. Kanne, Jr.

WSRC-TR-96-0087

April 1996

Page 3

\section{WELDING PROCEDURE DEVELOPMENT AND VESSEL FABRICATION}

A total of 31 vessels were welded during development of the welding process and fabrication of the vessels for loading, Table I. The first ten were used for development and the next two were for confirmation of the process using reject shells. Numbers 13 through 31 were made by the same procedure. Of these, two were examined metallographically, two were pneumatically burst tested, and twelve were loaded with a tritium mix.

Parameters for the girth welds were adapted from those used for a previous set of 21-6-9 storage vessels. The joint design was modified from that used previously to improve weld quality by using a chamfer on the outside surface and increasing the OD slightly to eliminate the possibility of undercutting of the external upset.

As a result of the evaluation of the welds on the initial vessels, a final joint design (as shown in Figure 1B) and a final set of welding conditions were chosen. The same welding parameters, shown below, were used for both the $304 \mathrm{~L}$ and the $316 \mathrm{~L}$ vessels.
Current, amperes
$62,700 \pm 1300$
Force, pounds
$42,500 \pm 300$
Time, seconds
one, in six equal pulses of 10 hertz each

Welding current was measured using Duffers meter \#82591 with its coil around the secondary loop of the Large Resistance Welder. The welding current was achieved with a percent heat setting of 70 to 72 using tap $\# 1$ on the transformers. Parameters were monitored during the welds using a Macintosh based data acquisition system. Force, current, voltage, and motion are plotted as a function of time. One of the plots is shown in Figure 4. Original data acquisition plots are printed in color with the parameters color coded. The six pulses are clearly visible in the voltage trace. The current meter holds the peak RMS current which increases slightly during the initial stages of the weld as the electrical resistance of the weld joint decreases. The force decreases slightly during the weld as the weld head moves down. Motion of the weld head shows that the deformation of the weld joint takes place during the last two pulses of the weld cycle.

Vessel components before welding consist of a top and bottom hemishell and a tube as shown in Figure 5A. The hemishells were joined at the girth using the welding process described above. The tubes were attached to the body using a side-bonded reclamation procedure. This procedure was demonstrated on test pieces to assure that the difference in materials could be accommodated. Hydrotest and metallographic results confirmed that there was no effect of using 21-6-9 stainless 
W. R. Kanne, Jr.

April 1996

WSRC-TR-96-0087

Page 4

steel tubes with the $304 \mathrm{~L}$ or $316 \mathrm{~L}$ bodies. The welding parameters for the tube attachment welds were 2250 pounds force with approximately 11,000 amperes current for 25 cycles (of 60 hertz).

Weld upset (extrusion of metal) occurs during girth welding and results in aswelded vessels as shown in Figure 5B. The weld upset is visible as a ring around the girth. This upset was machined off and a step was machined on the top of the vessel. The resulting completed vessels appeared as shown in Figure 6.

During development of the welding procedure, four vessels were pressure tested to failure using the hydrostatic pressurization equipment in Building 723-A. All four of these failed away from the weld in the curved region of the body as shown in Figure 7. Excellent weld strength was thereby demonstrated for a variety of welding conditions. Metallographic examination of the welds was used to access the weld configuration and bond quality. The force and current were varied to maximize weld quality.

\section{QUALIFICATION OF VESSELS FOR STORAGE TESTING}

All vessels were nondestructively examined using leak testing, proof testing, and $X$ ray radiography. Results are given in Table $I$. All vessels, both those used for the storage test and those used for destructive tests, passed all nondestructive tests. Detailed results of the proof tests and leak tests are documented in Ref. 6. Vessel length and the internal vessel volume were measured as an indication of the consistency of the finished vessels. Length and volume measurements were not as consistent as experienced previously.

Four of the series of vessels made for storage were destructively examined as a final qualification of the vessels. Two were pneumatically pressurized to failure in the $\mathrm{H}$ area facility. Both vessels, one of each material, failed in the body away from the weld area, Figure 8, indicating good weld strength.

A second vessel of each material, in addition to the one that was pressure tested, was sectioned for metallography. The overall configuration of the sectioned vessels is shown in Figure 9. Metallographic quality of the reclamation weld joining the 216-9 stainless steel stems to the 304L or 316L bodies was confirmed, as shown in

Figure 10. The vessels were sectioned through the opposite sides with the most and least upsetting to see the extremes in weld quality. Girth weld metallographic quality is shown in Figure 11 for 304L and Figure 12 for 316L. Quality of the welds is very good. The notch visible on the internal upset of these parts is undesirable, but has not been shown to cause any detrimental effects. High magnification photographs of the best and worst interface areas, left and right sides of Figures 11C and $12 \mathrm{C}$, indicate only a small amount of visible interface. Flow lines are present in 
the 316L metallographic section, Figure 12. These flow lines provide a clear illustration of the movement of the metal during upset welding.

A hardness traverse was run across a metallographic section of each material, Figures 13 and 14. The hardness data is plotted in Figure 15. It can be seen that the hardness of the forged material is maintained across the weld area. This indicates the strength gained by forging is maintained in the weld area. A fusion weld, by comparison, would loose considerable strength in the weld area compared to the forged vessel material, Ref. 1 . If these vessels had been fabricated using fusion welding (gas tungsten arc or electron beam welding), the weld area strength would have been reduced significantly.

\section{LOADING AND STORAGE TESTING}

Six 304L and six 316L vessels were loaded November 2-5, 1995. The two sets of vessels are shown in Figure 16 prior to loading. Both sets are stored at $71^{\circ} \mathrm{C}$ in the Materials Test Facility, Building 232-H.

\section{CONCLUSIONS}

Design, procedure development, fabrication, nondestructive testing and destructive testing of forged 304L and 316L upset welded vessels for storage testing was completed. Finished vessels qualified in all respects for tritium loading and storage. The vessels were loaded and are currently in storage at $71^{\circ} \mathrm{C}$. These two sets of vessels are the first forged $304 \mathrm{~L}$ and 316L vessels fabricated using resistance upset welding. Examination of these vessels following storage will be used to evaluate the acceptability of the upset welding process for long-term tritium service.

\section{ACKNOWLEDGMENTS}

This program was funded jointly by the Los Alamos National Laboratory and the Albuquerque Operations Office. Leo Michels of Los Alamos provided direction for the program. Material for fabrication of the vessels was forged at the EG\&G Oxnard Facility.

The program was carried out by the Applied Science and Engineering Department of the Savannah River Technology Center. Metallography was by done by Building 723-A Metallographic Laboratory personnel under the direction of Tina Stefek. Proof and leak testing of vessels was done by Building 723-A High Pressure Laboratory personnel under the direction of Wayne Good. 
W. R. Kanne, Jr.

April 1996
WSRC-TR-96-0087

Page 6

Processing of the vessels by the Tritium department was directed by Jim Dollar and Bob Alexander. Storage of the vessels is being directed by Ed Majzlik and Tonya Dominguez.

\section{REFERENCES}

1. W. R. Kanne, Jr., "Solid-State Resistance Welding of Cylinders and Spheres", Welding Journal, p 33-38, May 1986.

2. W. R. Kanne, Jr., "Upset Welding Large Spherical Containers, WSRC-TR-91-57, March 1991.

3. W. R. Kanne, Jr., "Upset Welding Process for 21-6-9 Spherical Vessels (U)", WSRC-TR-93-015, February 1993.

4. "Cleaning and Packaging Stainless Steel Components", Equipment and Materials Technology Department Procedure Manual L9.3-4152, Rev. 0, December 3, 1991.

5. W. R. Kanne, Jr., "Oakite Procedure for Immersion Cleaning of Stainless Steel Parts, Rev. 1/4/94.

6. "EES Proof / Leak Test Data Sheet (U)", Basis No. SRT-SPS-940177, Record Nos. 445-457, 600-606, September 1994. 
W. R. Kanne, Jr.

April 1996
WSRC-TR-96-0087

Page 7

Table I

\section{STATUS OF F-SERIES VESSELS}

\begin{tabular}{|c|c|c|c|}
\hline$\frac{\text { Vessel }}{\text { No. }}$ & Material & Cleaning & Vessel Use \\
\hline F-1 & $316 \mathrm{~L}$ & Nitradd & Burst in 723-A \\
\hline $\mathrm{F}-2$ & $316 \mathrm{~L}$ & Nitradd & Metallographically examined \\
\hline F-3 & $304 \mathrm{~L}$ & Nitradd & Metallographically examined \\
\hline $\mathrm{F}-4$ & $304 \mathrm{~L}$ & Nitradd & Burst in 723-A \\
\hline F-5 & $304 \mathrm{~L}$ & Nitradd & On hold \\
\hline F-6 & $304 \mathrm{~L}$ & Nitradd & Metallographically examined \\
\hline F-7 & $316 \mathrm{~L}$ & Nitradd & Burst in $723-\mathrm{A}$ \\
\hline F-8 & $316 \mathrm{~L}$ & Nitradd & On hold \\
\hline F-9 & $316 \mathrm{~L}$ & Nitradd & On hold \\
\hline F-10 & $316 \mathrm{~L}$ & Nitradd & Burst in 723-A \\
\hline F-11 & $316 \mathrm{~L}$ & Nitradd & On hold: reject shells (thin wall on top shell) \\
\hline F-12 & $304 \mathrm{~L}$ & Oakite & On hold: reject shells (grooves inside surface) \\
\hline F-13 & $304 \mathrm{~L}$ & Nitradd & Storage quality: metallographically examined \\
\hline F-14 & $304 \mathrm{~L}$ & Nitradd & Storage quality: loaded for storage \\
\hline F-15 & $304 \mathrm{~L}$ & Nitradd & Storage quality: loaded for storage \\
\hline F-16 & $304 \mathrm{~L}$ & Nitradd & On hold: Discolored stem \\
\hline F-17 & $304 \mathrm{~L}$ & Oakite & Storage quality: loaded for storage \\
\hline F-18 & $304 \mathrm{~L}$ & Oakite & Storage quality: loaded for storage \\
\hline F-19 & $304 \mathrm{~L}$ & Oakite & Storage quality: loaded for storage \\
\hline F-20 & $304 \mathrm{~L}$ & Nitradd & Storage quality: burst in $\mathrm{H}$-area \\
\hline F-21 & $304 \mathrm{~L}$ & Nitradd & Storage quality: loaded for storage \\
\hline F-22 & $316 \mathrm{~L}$ & Oakite & Storage quality: burst in $\mathrm{H}$-area \\
\hline F-23 & $316 \mathrm{~L}$ & Nitradd & Storage quality: loaded for storage \\
\hline F-24 & $316 \mathrm{~L}$ & Nitradd & Storage quality: loaded for storage \\
\hline F-25 & $316 \mathrm{~L}$ & Oakite & Storage quality: loaded for storage \\
\hline F-26 & $316 \mathrm{~L}$ & Oakite & Storage quality: loaded for storage \\
\hline F-27 & $316 \mathrm{~L}$ & Oakite & Storage quality: loaded for storage \\
\hline F-28 & $316 \mathrm{~L}$ & Nitradd & Storage quality: loaded for storage \\
\hline F-29 & $316 \mathrm{~L}$ & Nitradd & Storage quality: metallographically examined \\
\hline F-30 & $316 \mathrm{~L}$ & Nitradd & Storage quality: available \\
\hline F-31 & $316 \mathrm{~L}$ & Nitradd & Storage quality: available \\
\hline
\end{tabular}


W. R. Kanne, Jr.

April 1996
WSRC-TR-96-0087

Page 8

\section{Table II}

TEST RESULTS FOR 304L AND 316L VESSELS

Test

Leak Test

Proof Test

X-Ray

Shrinkage

Internal Volume

Hydrostatic Burst

Pneumatic Burst

Metallography
No. of Vessels

304L $\quad$ 316L

14

17

17

17

10

10

3

1

2 $\underline{\text { Result }}$

No Leaks

No Failures

OK

$0.125 \pm 0.017 \mathrm{in}$.

$29.0 \pm 0.8 \mathrm{cc}$

Failure in Body at $\sim 45,000$ psi

Failure in Body at $\sim 45,000$ psi

Excellent Bond 
W. R. Kanne, Jr. April 1996
WSRC-TR-96-0087

Page 9

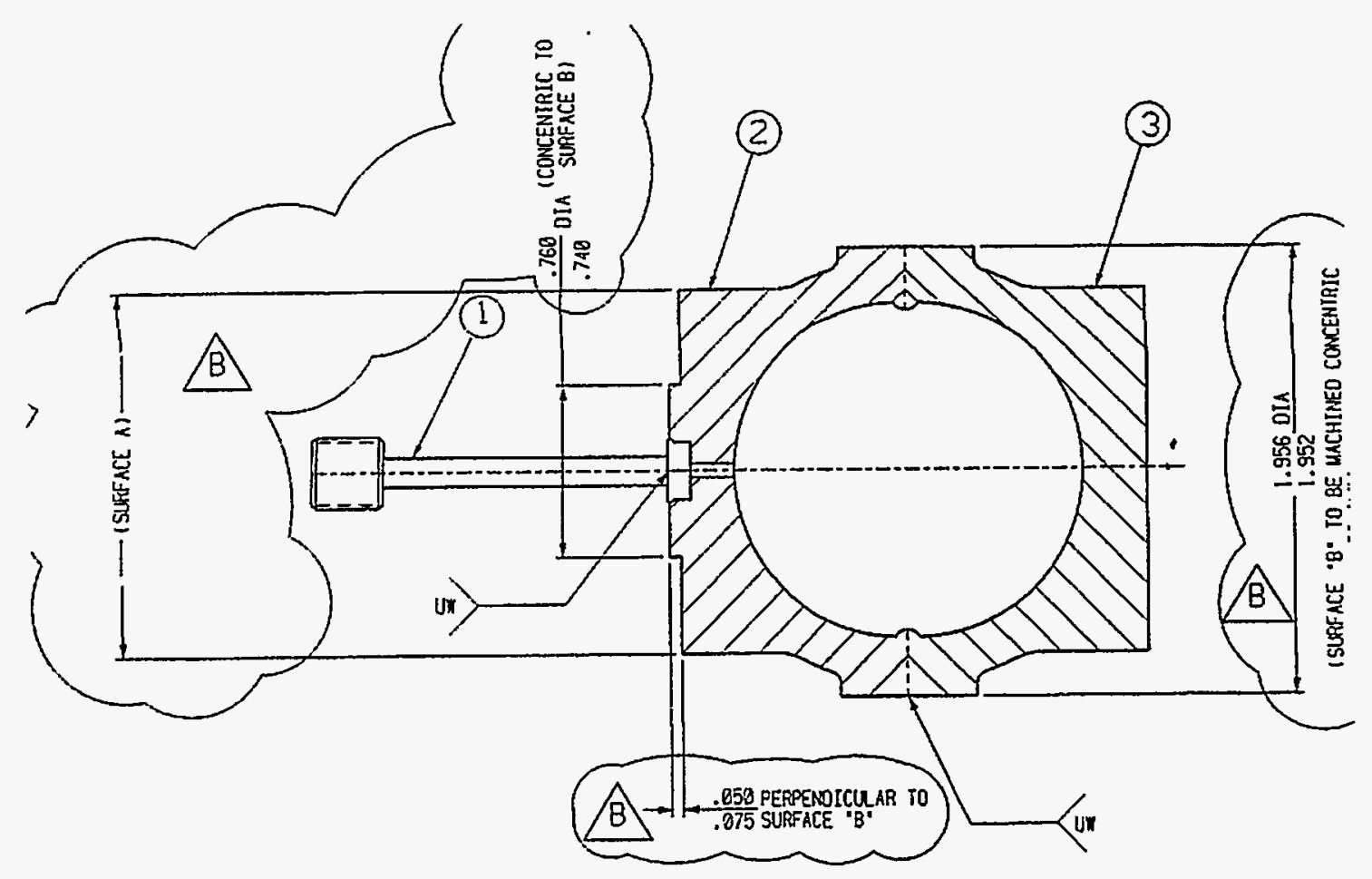

A. Vessel assembly with final machining.

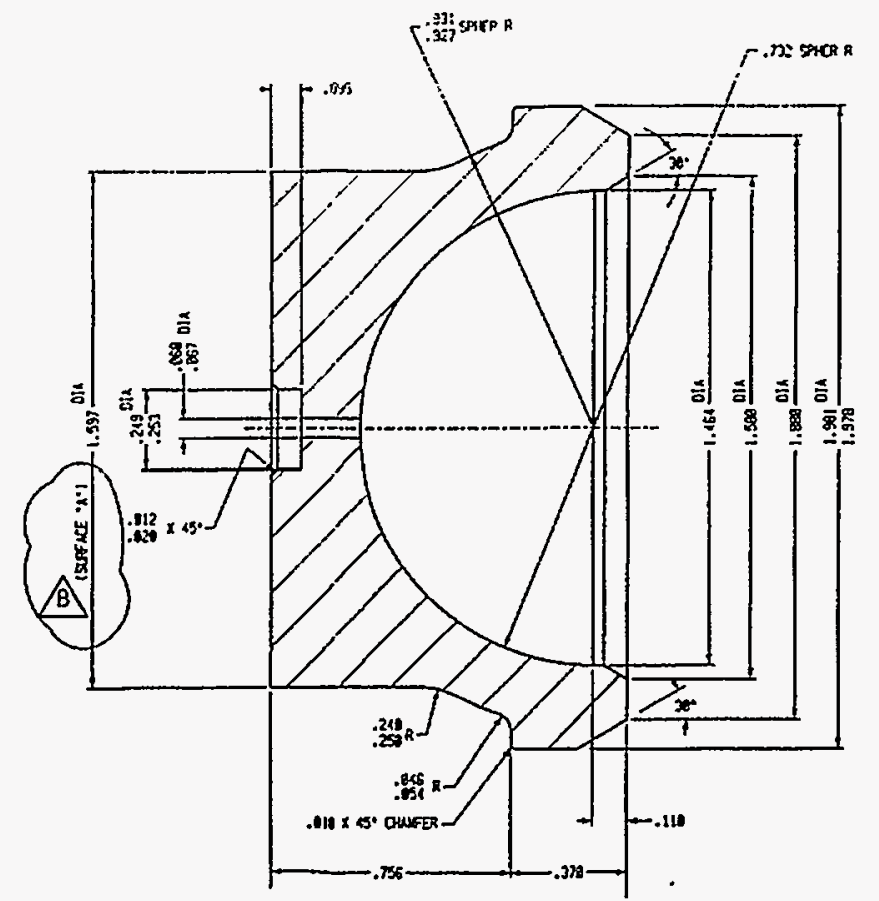

B. Top Cap. (bottom cap same without $1 / 16$ inch hole or counterbore for tube)

Figure 1. Vessel design. (from drawing EES-22045-R3-006) 
W. R. Kanne, Jr.

April 1996
WSRC-TR-96-0087

Page 10

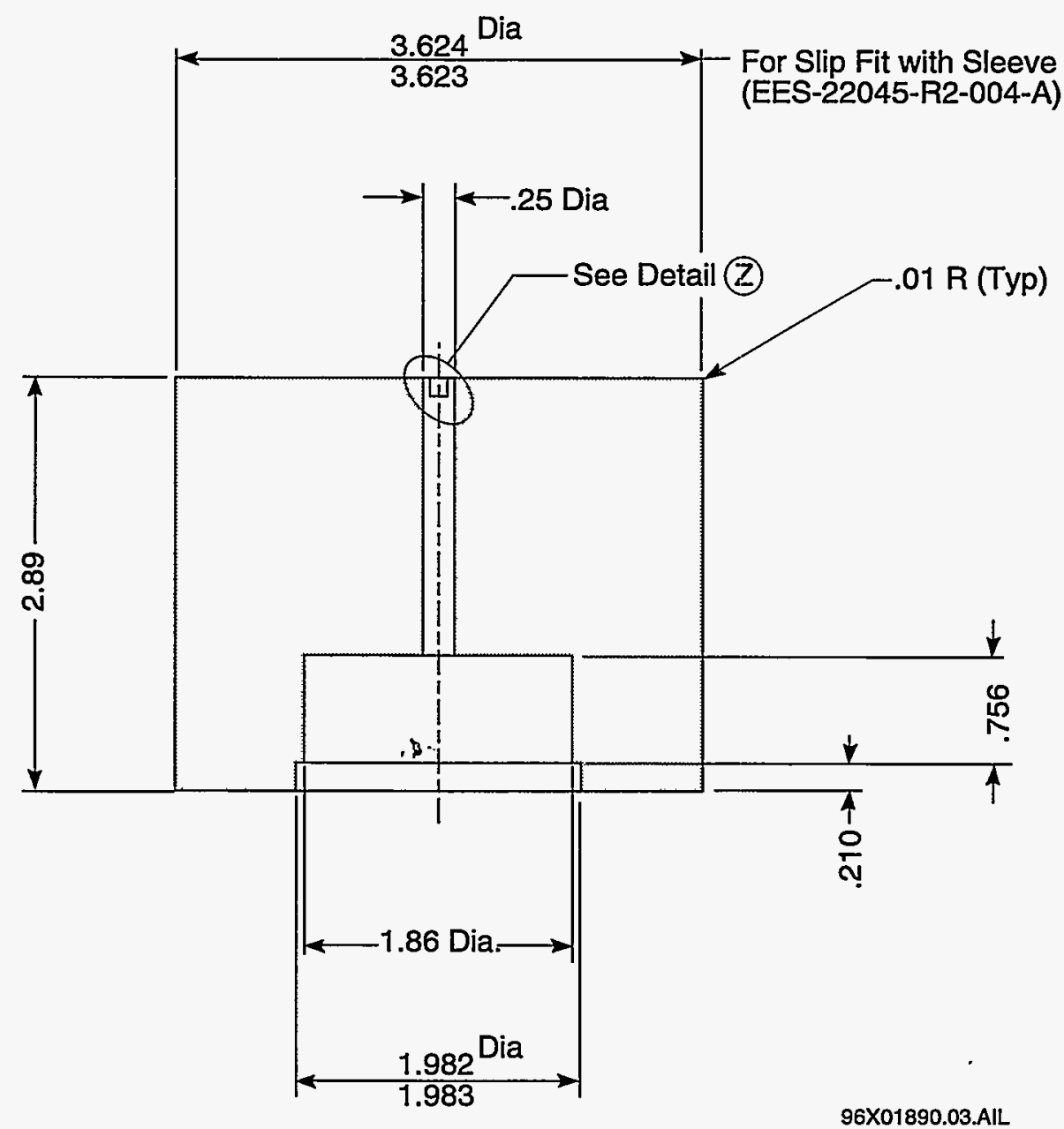

$\sqrt[63]{ }$ Finish all Surfaces Except the .25 Dia Hole

Large F46 Electrode

Matt: Class II Copper Reqd: 1

EES-22045-R4-005-A

Figure 2. Electrode design. (bottom and top electrode identical) 
W. R. Kanne, Jr.

WSRC-TR-96-0087

April 1996

Page 11

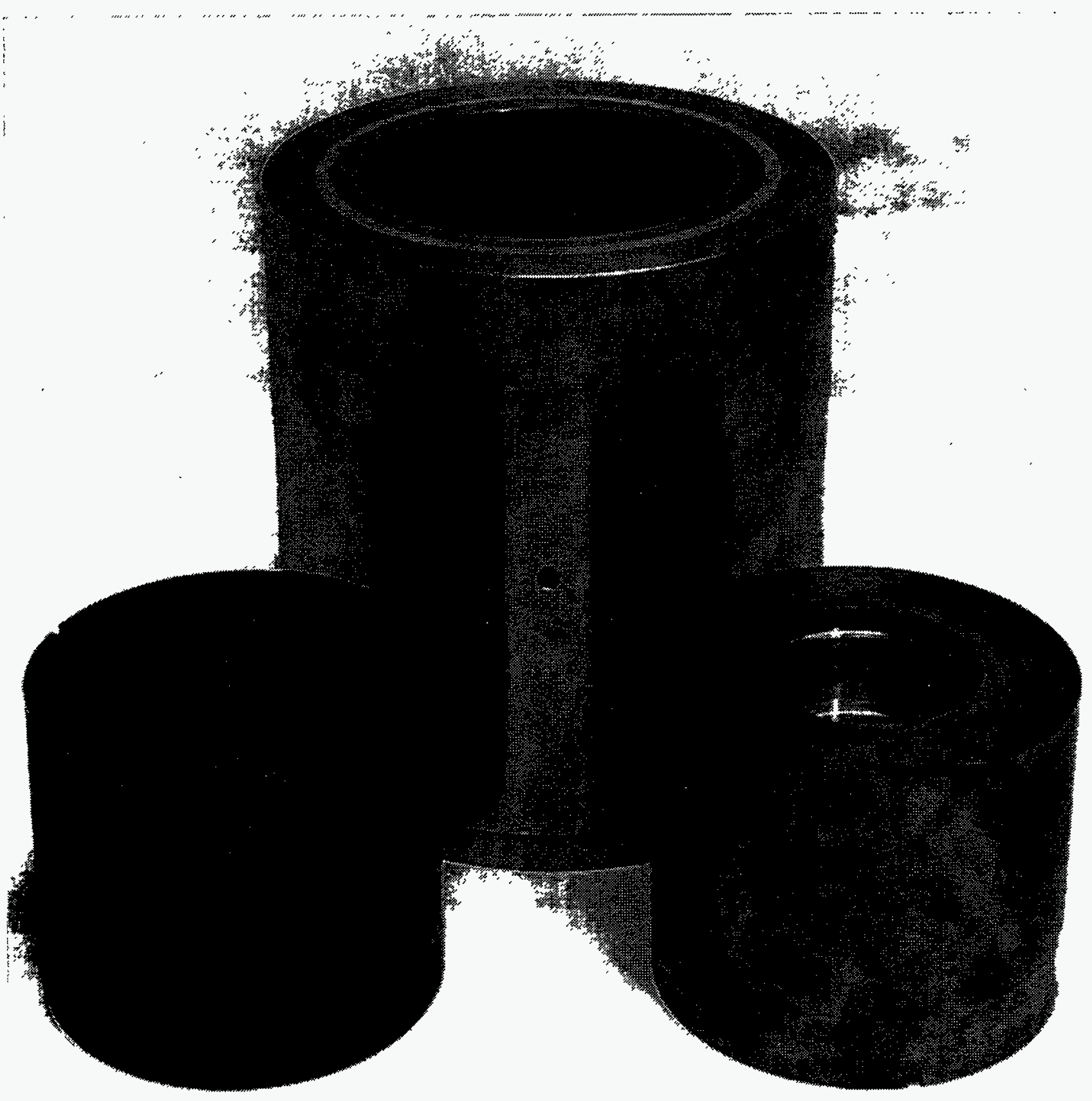

Figure 3. Fixtures for welding vessels. Electrodes in foreground showing top and bottom view. Alignment sleeve behind electrodes. (0.8X, EE53183) 
W. R. Kanne, Jr.

April 1996
WSRC-TR-96-0087

Page 12

\section{DONE

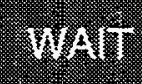

Weld Voltage

\section{Force}

Peak Current

Position

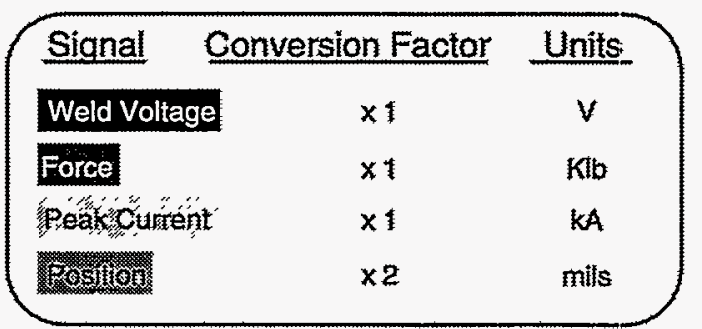

\begin{tabular}{c} 
Final Current \\
\hline 61.6 \\
\hline Initial Force \\
\hline 42.3 \\
\hline Displacement \\
\hline 93 \\
\hline
\end{tabular}

Filename

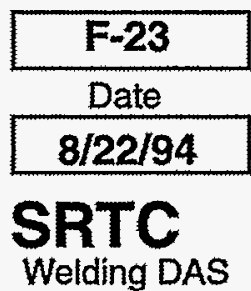

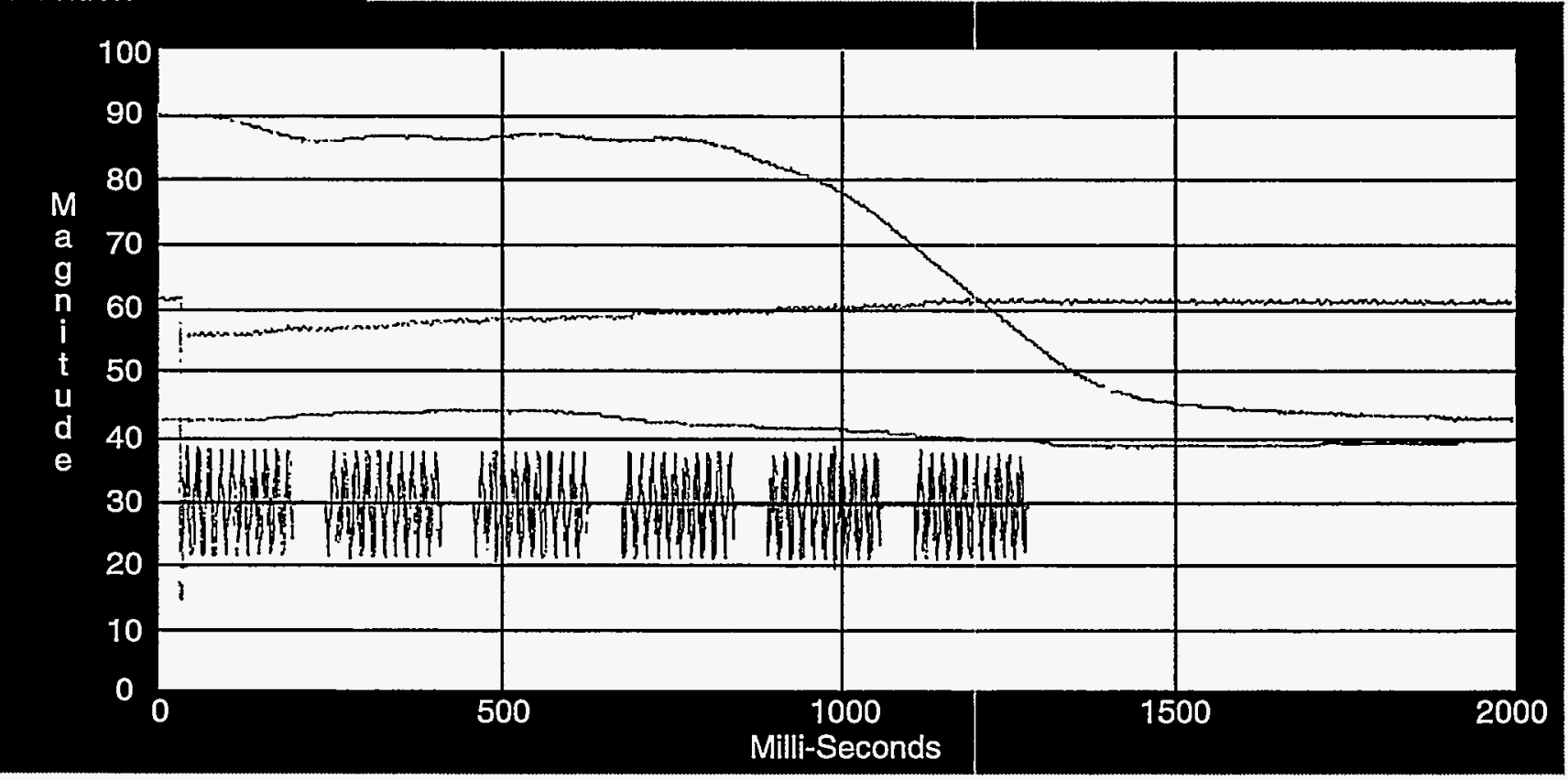

96X01890.01.AlL

Figure 4. Data acquisition trace of weld motion (top), current, force, and voltage (bottom). 
W. R. Kanne, Jr.

April 1996
WSRC-TR-96-0087

Page 13

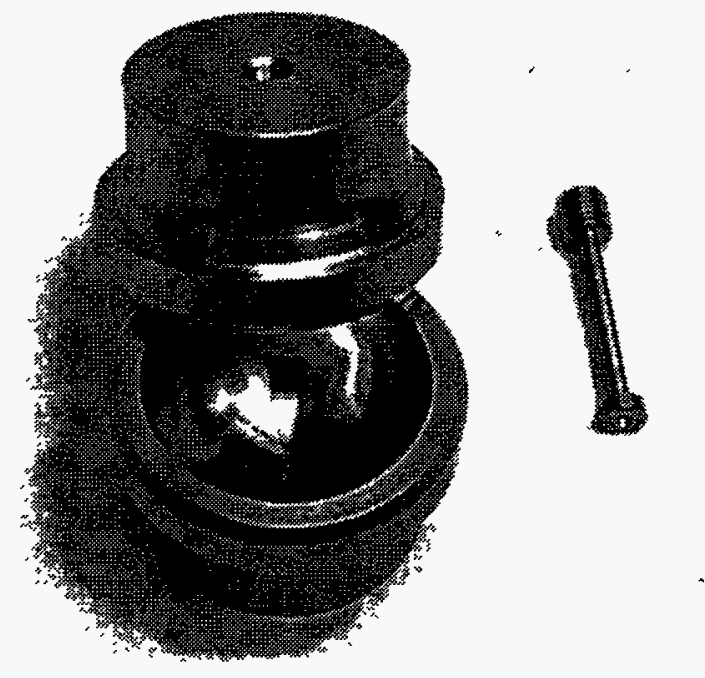

A. Shells and tube before welding (0.7X, EE53656)

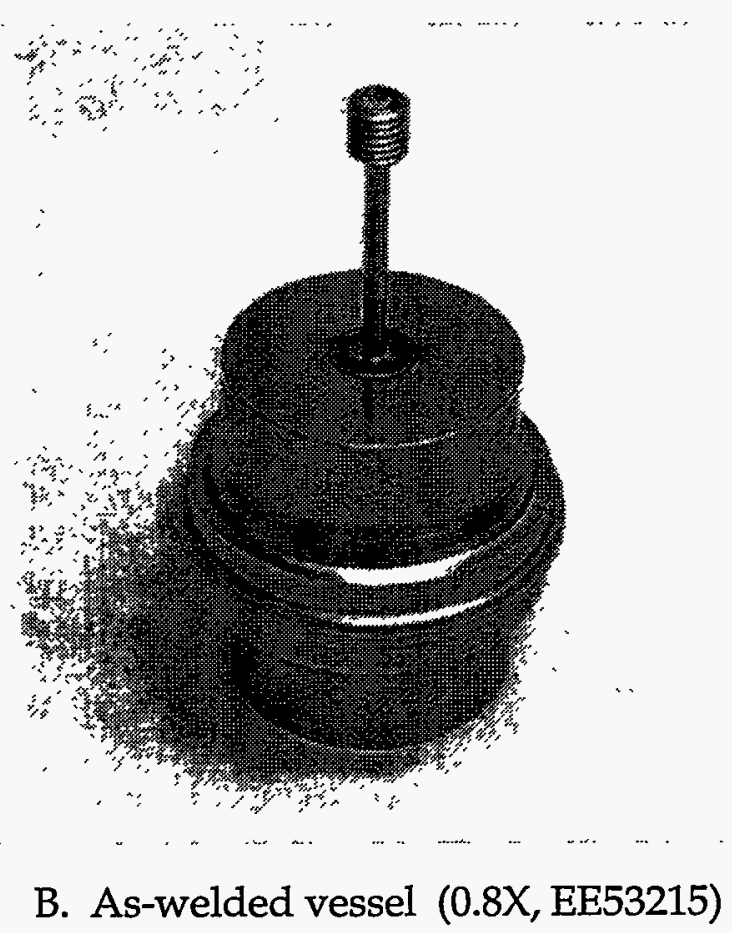

Figure 5. Fabrication of vessels. 
W. R. Kanne, Jr.

April 1996
WSRC-TR-96-0087

Page 14

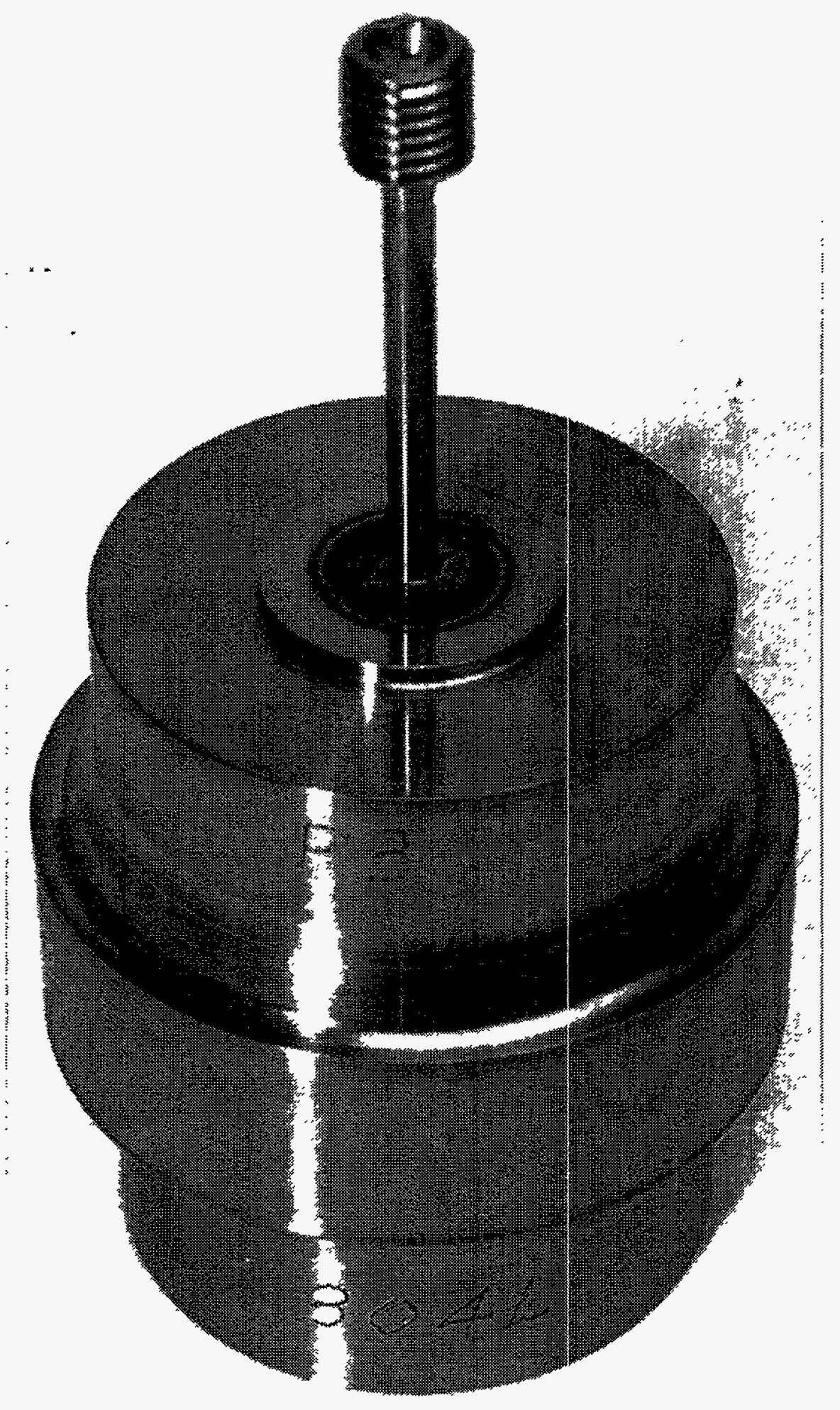

Figure 6. Finished vessel (external upset removed and top step machined). (2.0X, EE53184) 
W. R. Kanne, Jr.

April 1996
WSRC-TR-96-0087

Page 15

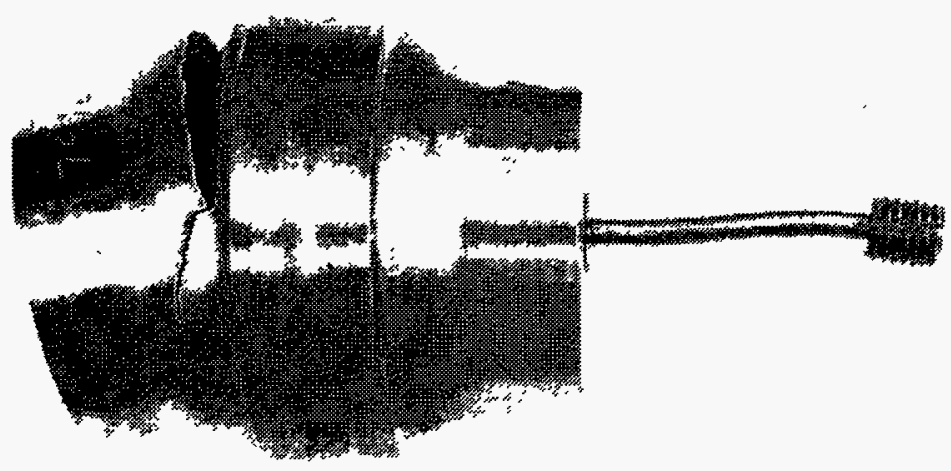

A. Vessel F-1 made from 316L stainless steel (1X, EE53179)

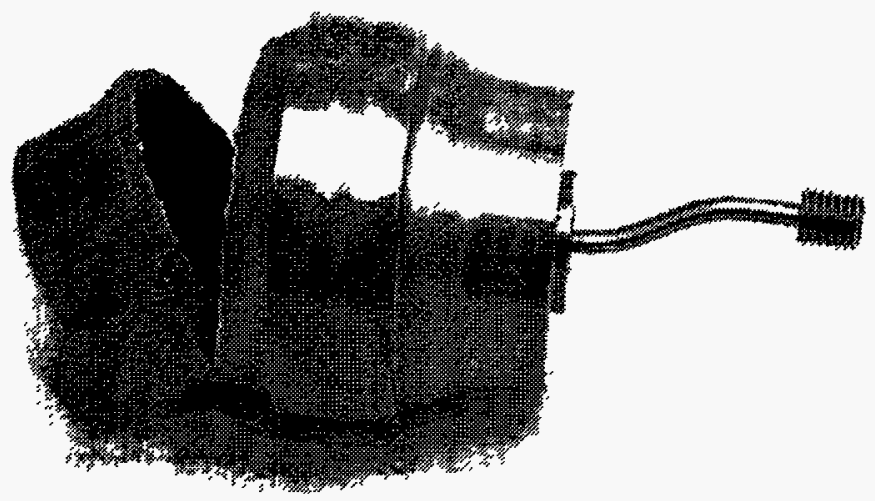

B. Vessel F-4 made from 304L stainless steel (1X, EE53183)

Figure 7. Hydrostatic Pressure Tests 
W. R. Kanne, Jr.

April 1996
WSRC-TR-96-0087

Page 16

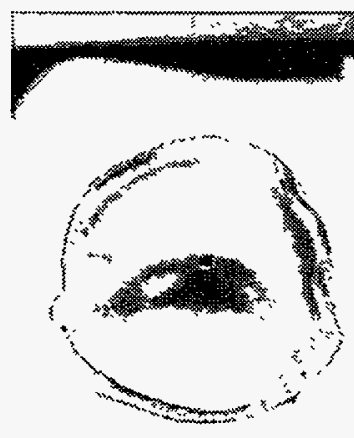

A. $304 \mathrm{~L}$, Face view of fracture
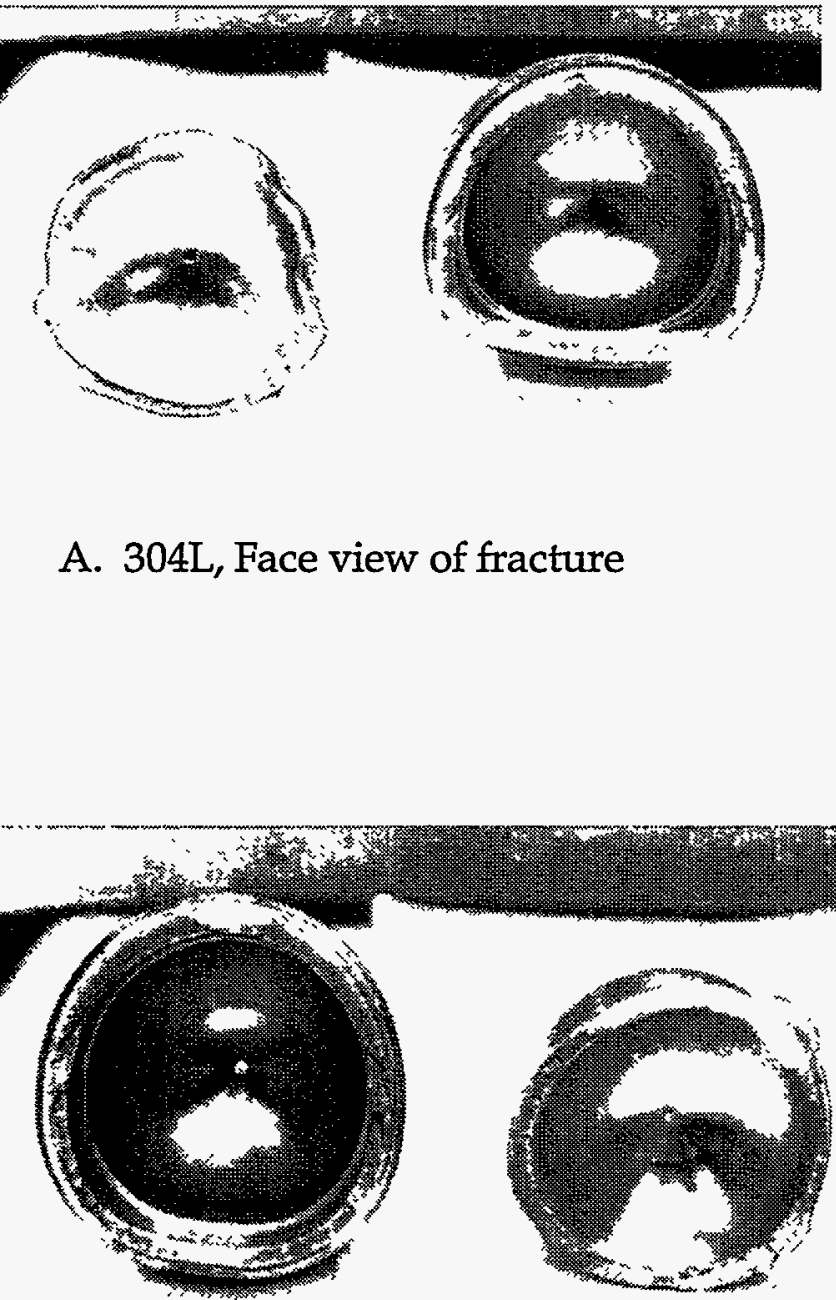

C. $316 \mathrm{~L}$, Face view of fracture

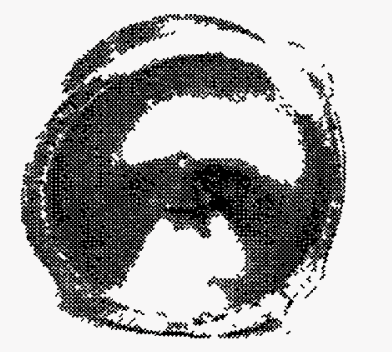

B. 304L, Side view (vessel F-20)
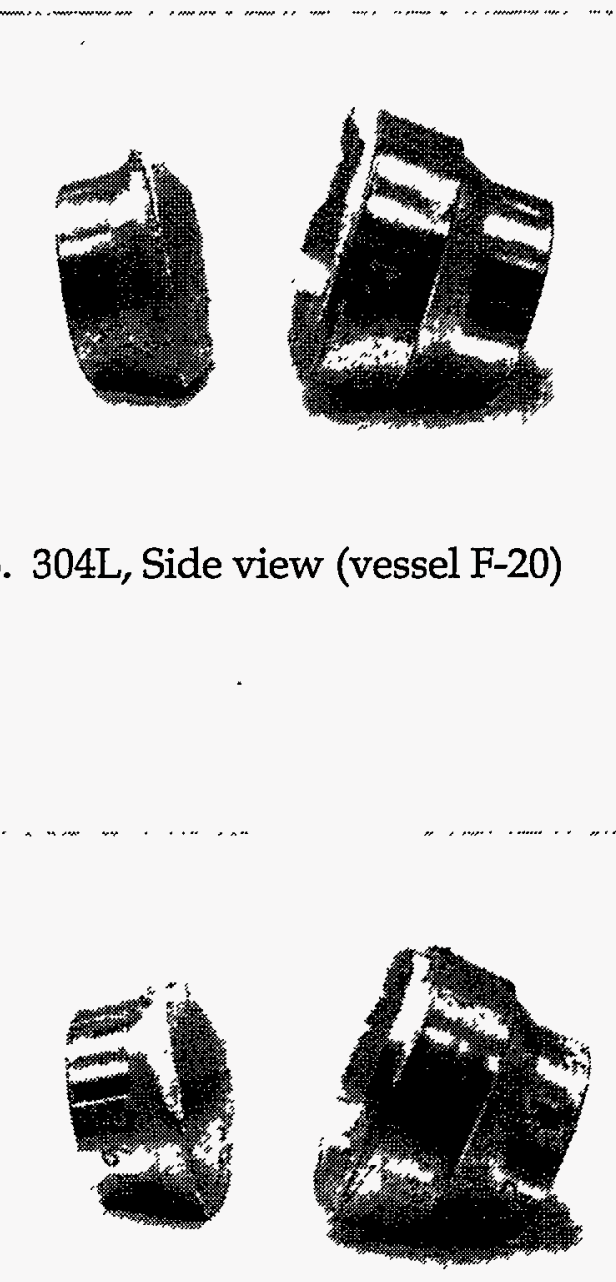

Figure 8. Pneumatic pressure tests to failure of vessels taken from the series made for storage. These vessels were chosen with maximum internal volume (minimum upset and therefore minimum strength) from the set used for storage. Note that the failure occurred away from the upset girth weld, indicating good weld strength. (1X, S-20600,1; S-20553,4) 
W. R. Kanne, Jr.

April 1996

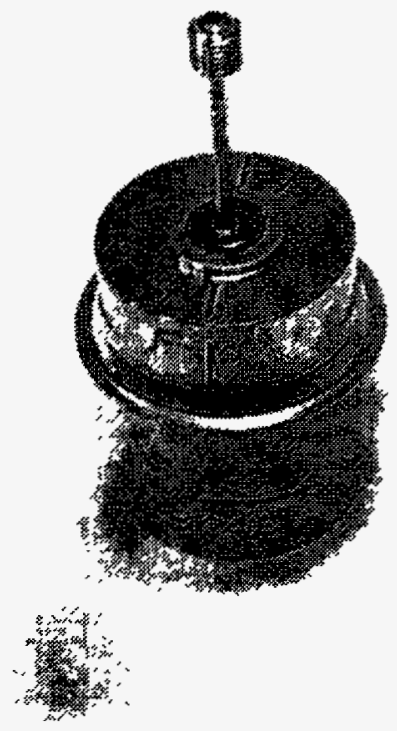

A. Vessel before sectioning (1.0X, EE53765)
WSRC-TR-96-0087

Page 17

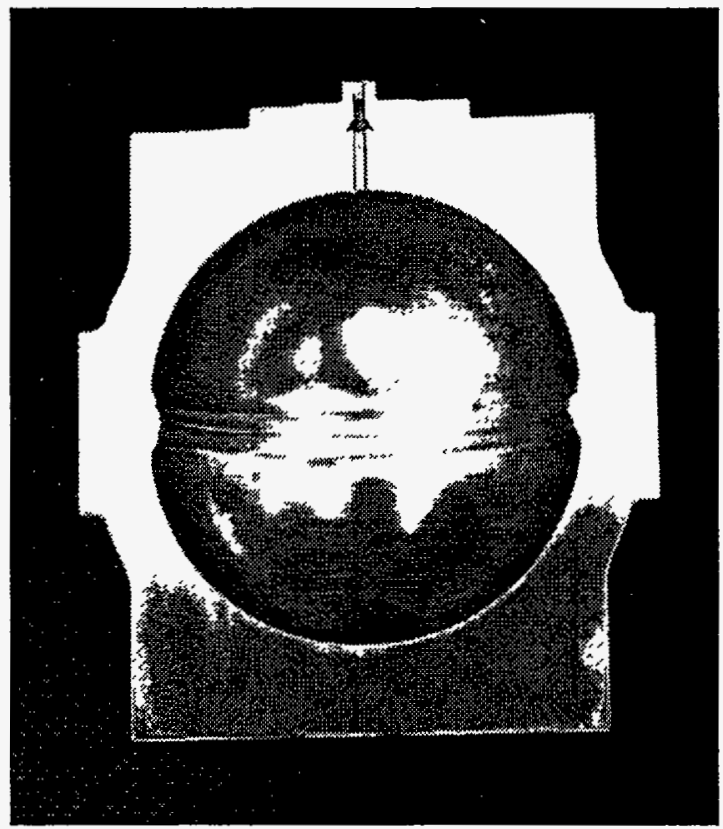

B. Sectioned vessel (1X, EE53698)
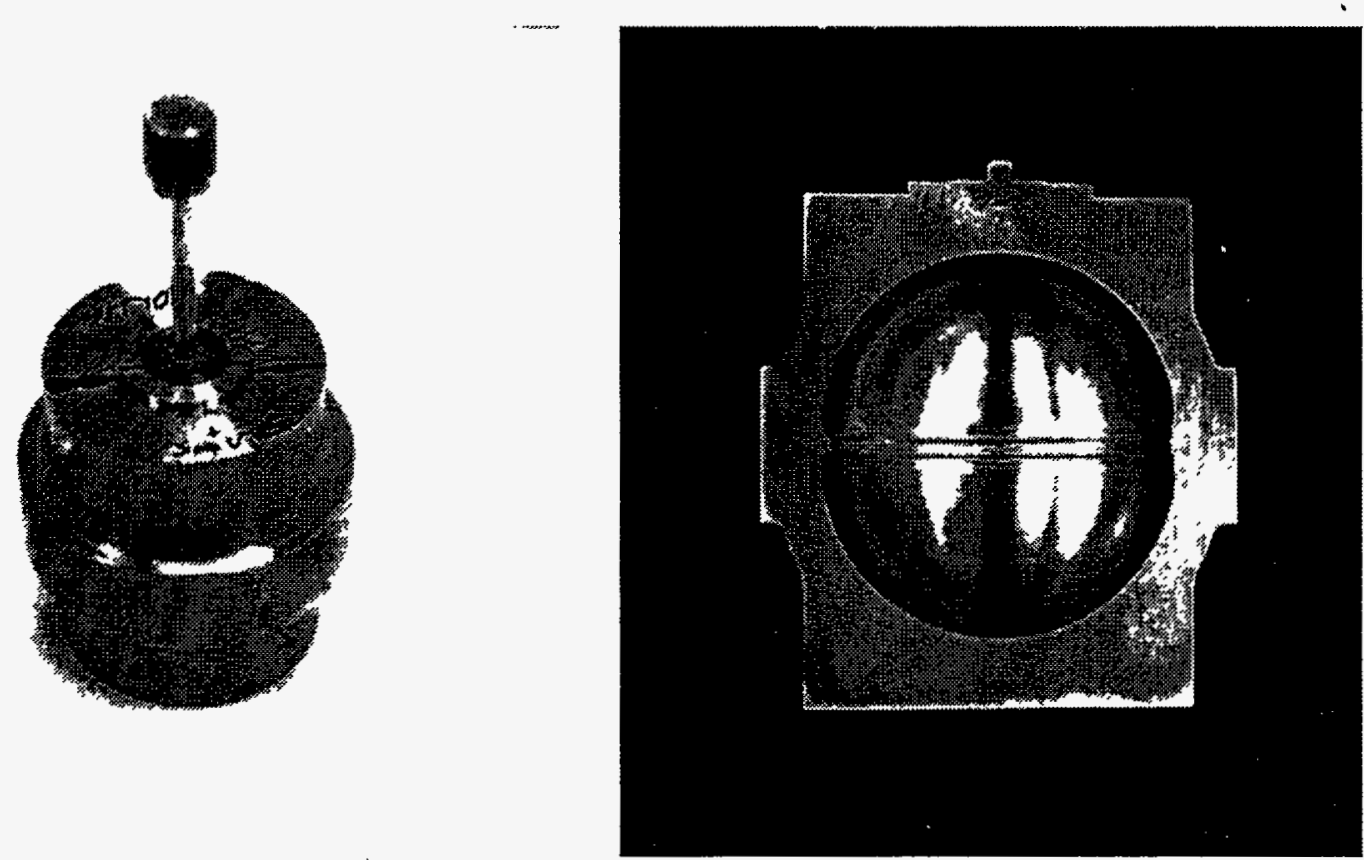

C. Vessel before sectioning (1.0X, EE53796-1) D. Sectioned vessel (1X, EE53796-2) .

Figure 9. Metallographic preparation of vessels from the series máde for storage. A and $B$ above are $304 \mathrm{~L}$ vessel F-13 and $C$ and D above are $316 \mathrm{~L}$ vessel F-29. Vessels were sectioned through maximum and minimum upset (note difference in configuration of internal upset on left and right sides). 
W. R. Kanne, Jr.

April 1996
WSRC-TR-96-0087

Page 18

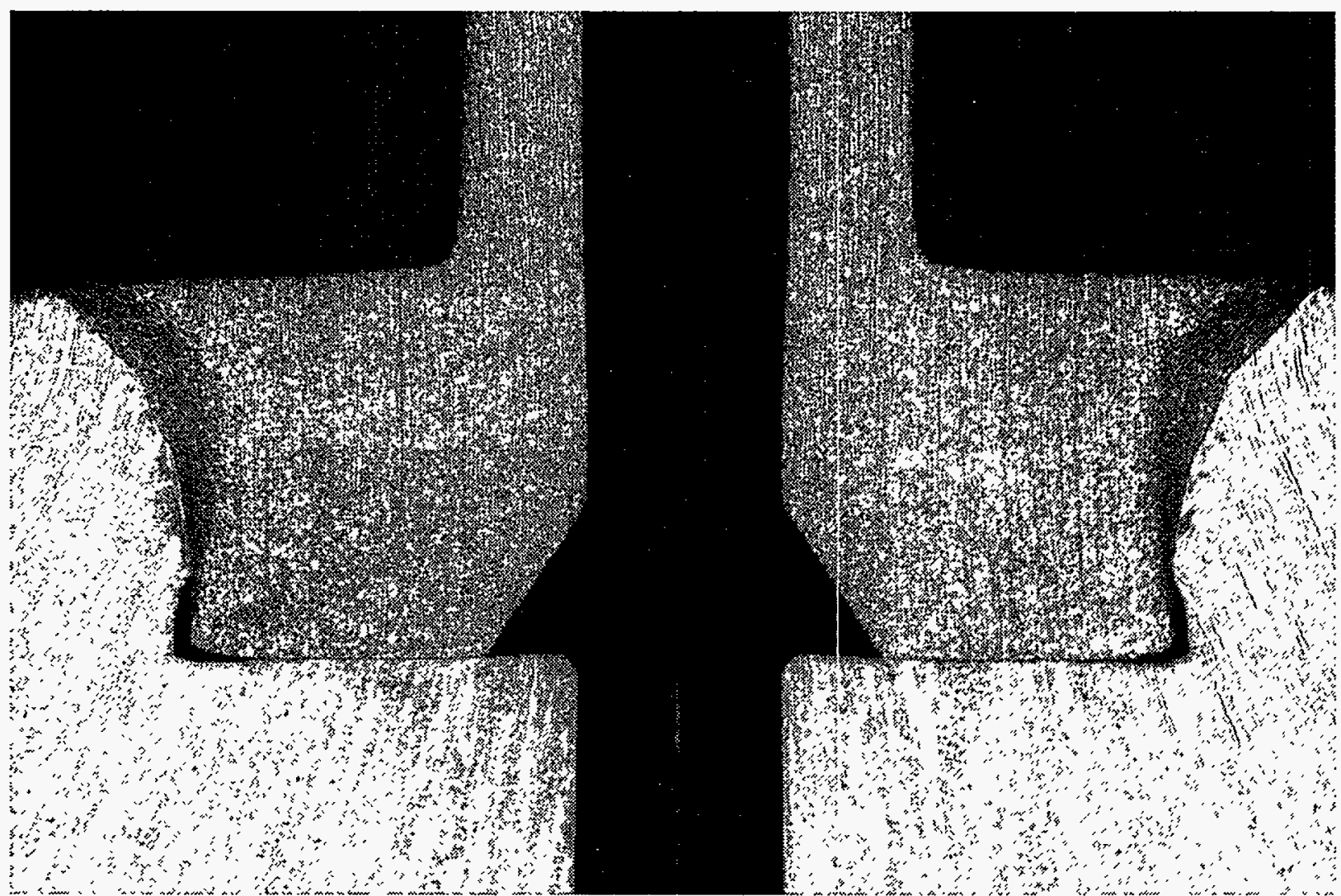

Figure 10. Tube attachment weld joining 21-6-9 stem to 316L body. (20X, EE53180) 
W. R. Kanne, Jr. April 1996

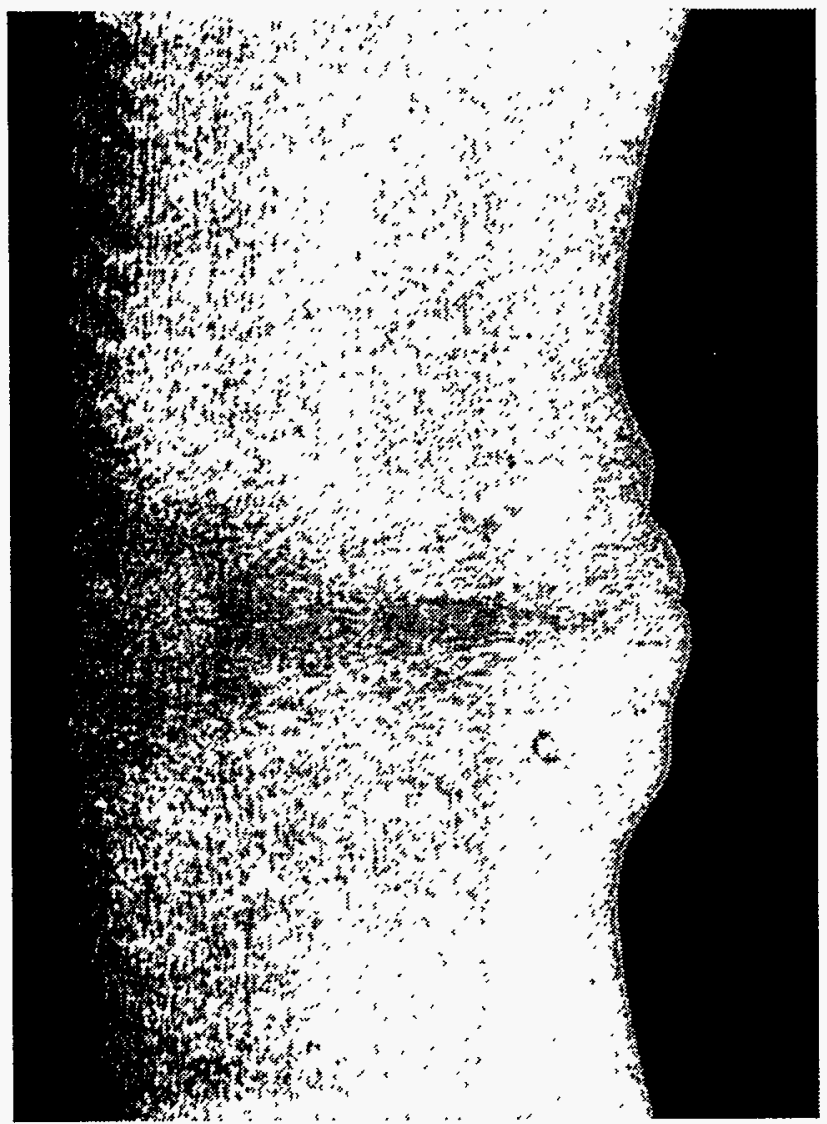

A. Left side at 10X (EE53766-2)
WSRC-TR-96-0087

Page 19

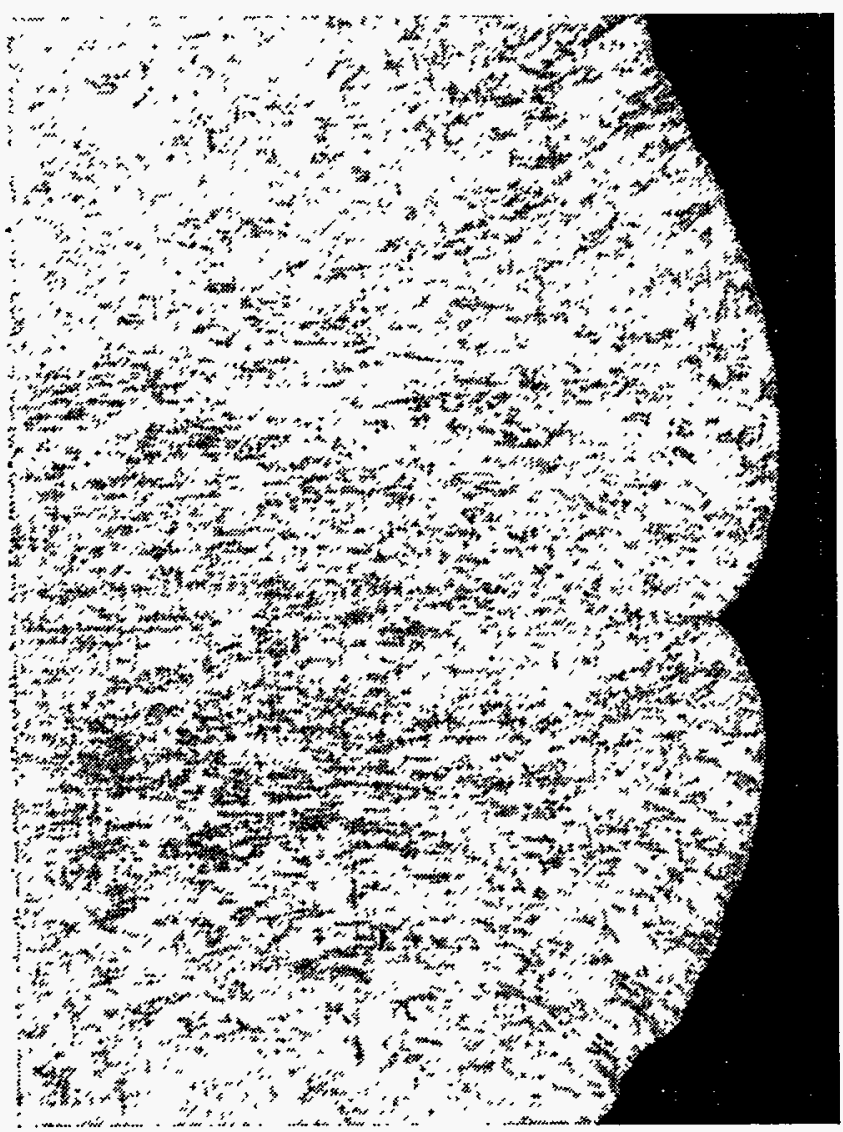

B. Left side at 50X (EE53767-1)

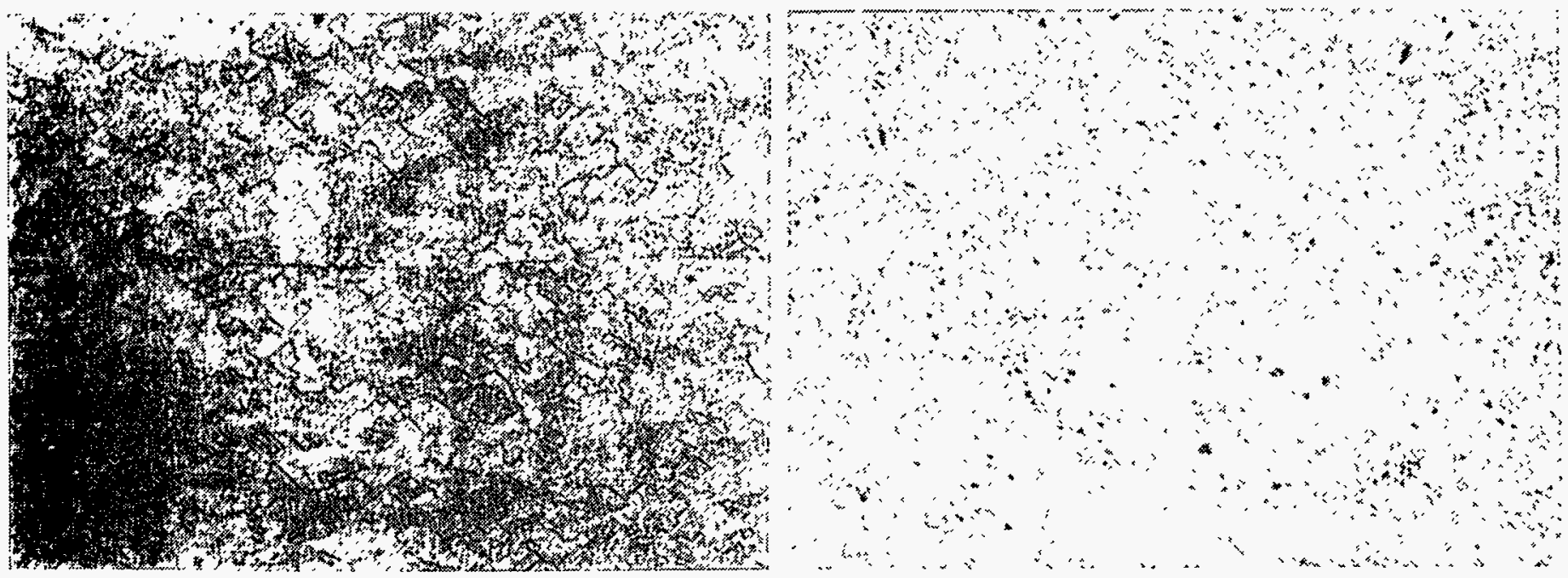

C. High Magnification (200X, EE5367-2 \& EE53768)

Figure 11. Metallographic analysis of 304L vessel F-13. 
W. R. Kanne, Jr.

April 1996

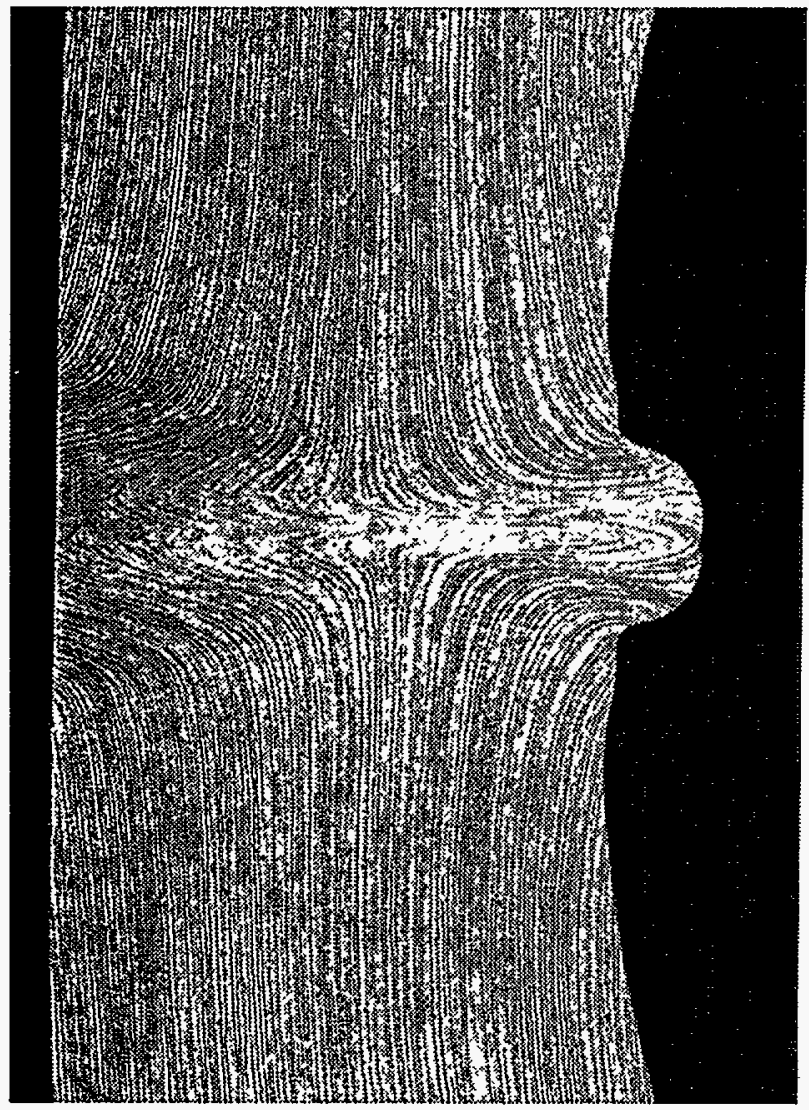

A. Left side at 10X (EE53799)

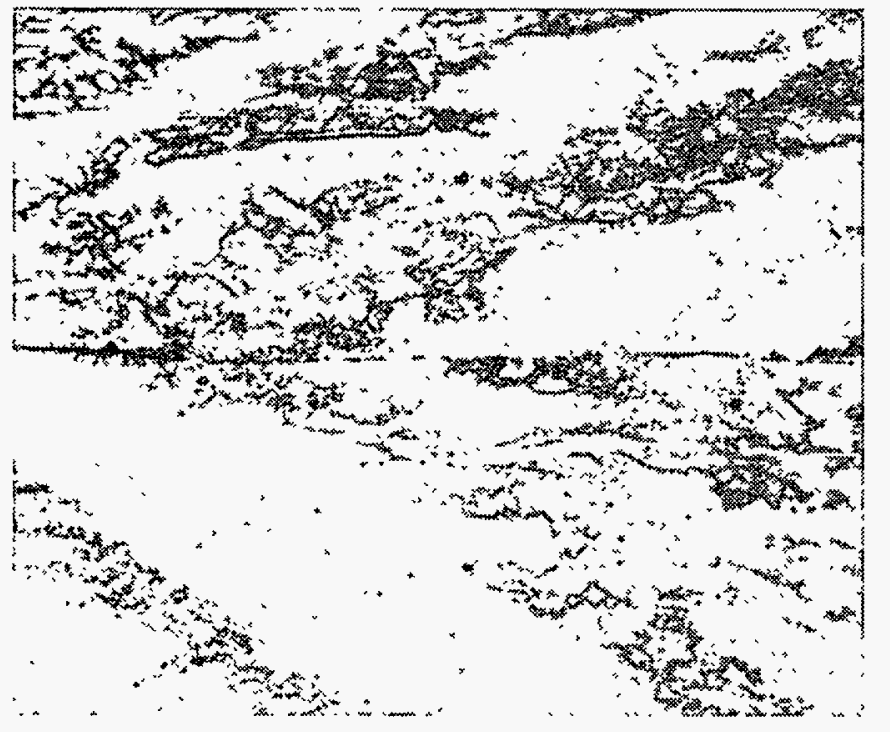

WSRC-TR-96-0087

Page 20

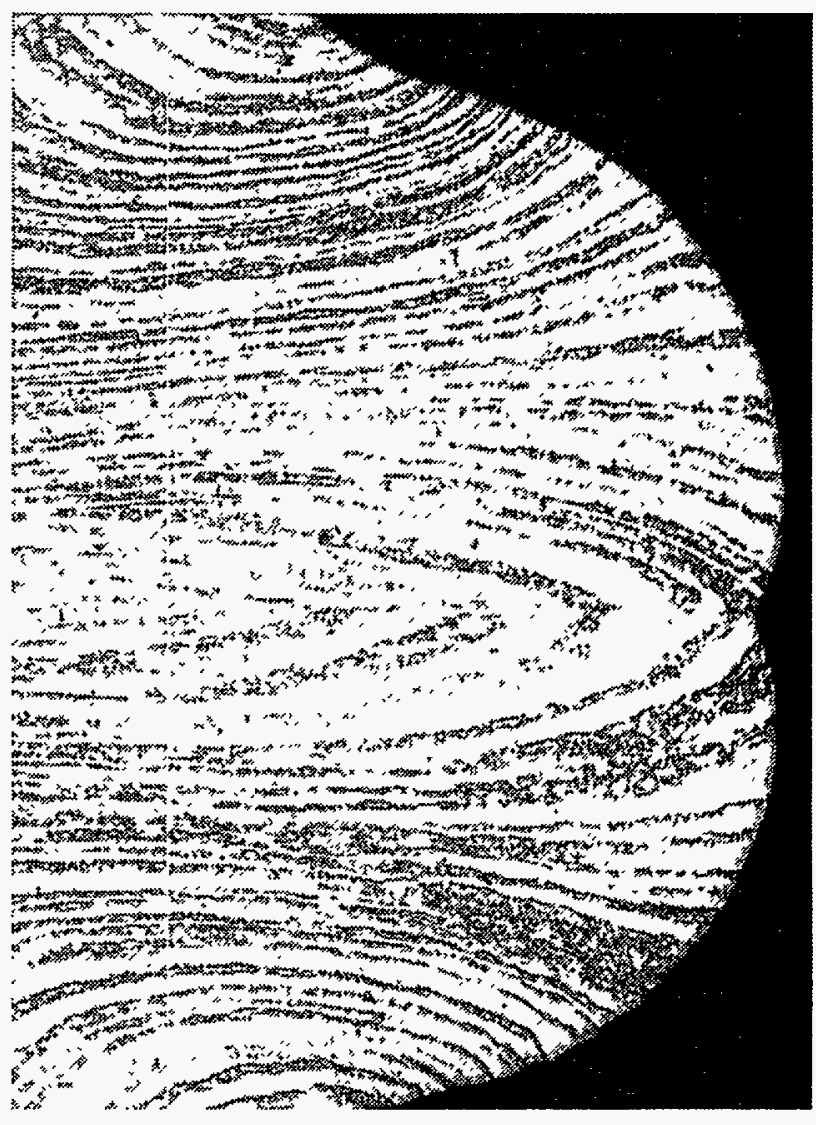

B. Left side at 50X (EE53801-1)

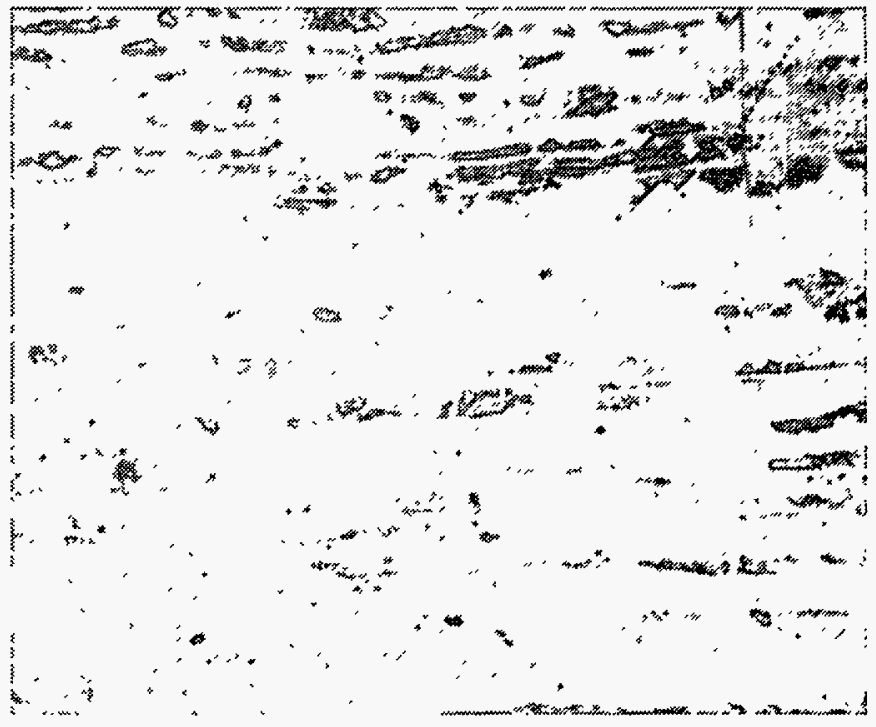

C. High Magnification (200X, EE53800 \& EE53801-2)

Figure 12. Metallographic analysis of 316L vessel F-29. 
W. R. Kanne, Jr.

WSRC-TR-96-0087

April 1996

Page 21

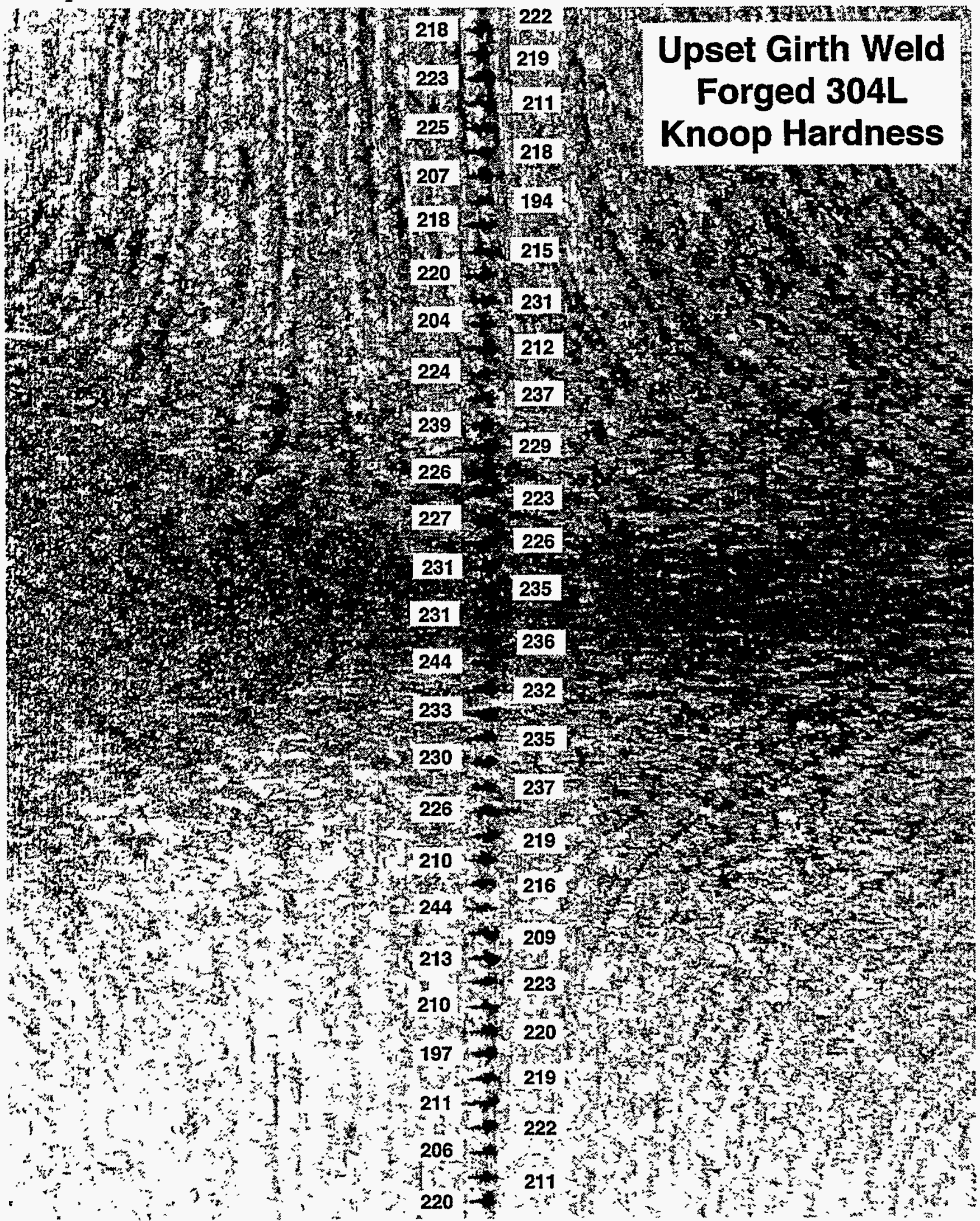

Figure 13. Hardness traverse across the weld in 304L vessel F-13. (50X, EE54196) 
W. R. Kanne, Jr.

April 1996

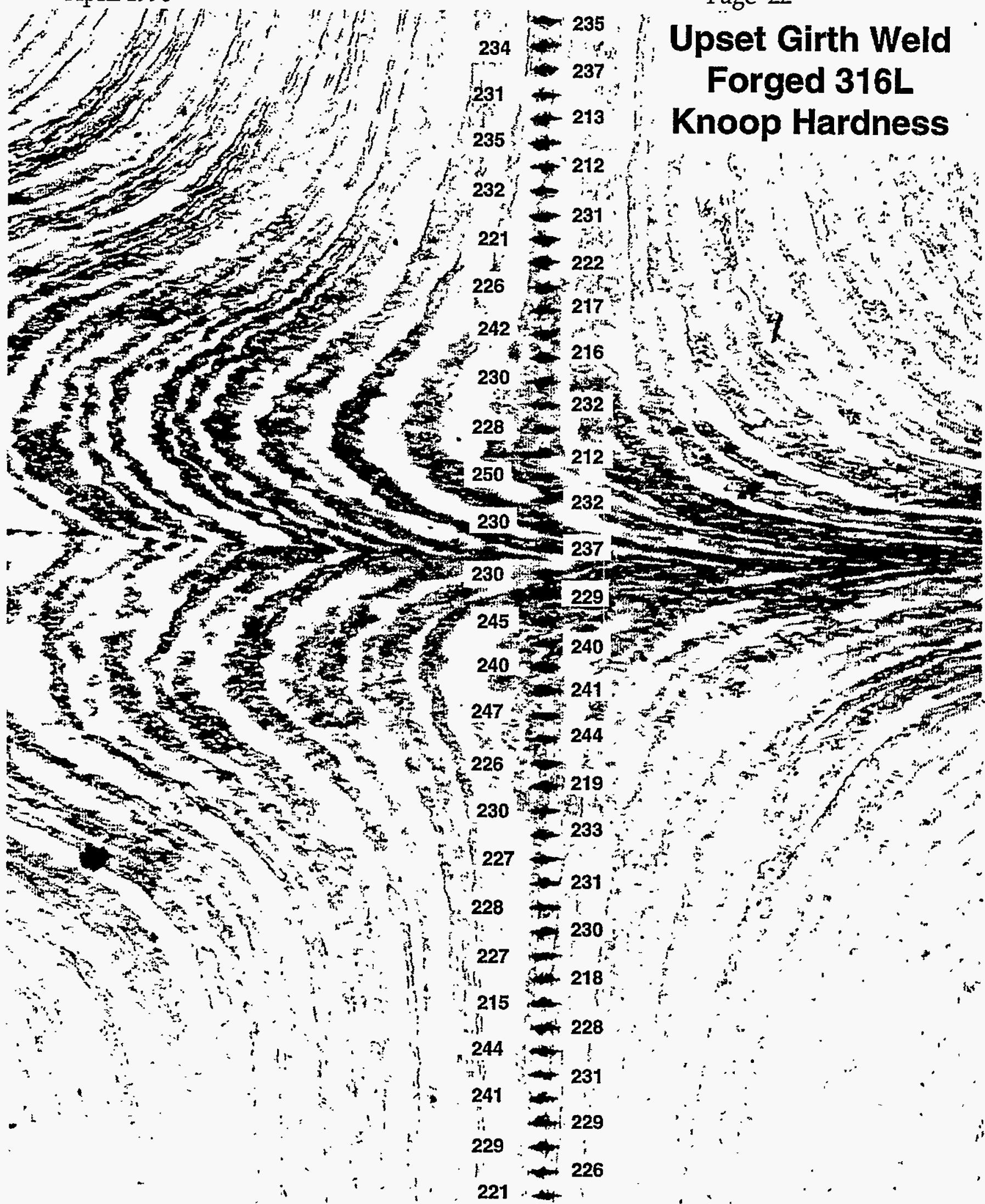

Figure 14. Hardness traverse across the weld in 316L vessel F-29. (50X, EE54197) 
W. R. Kanne, Jr.

April 1996
WSRC-TR-96-0087

Page 23
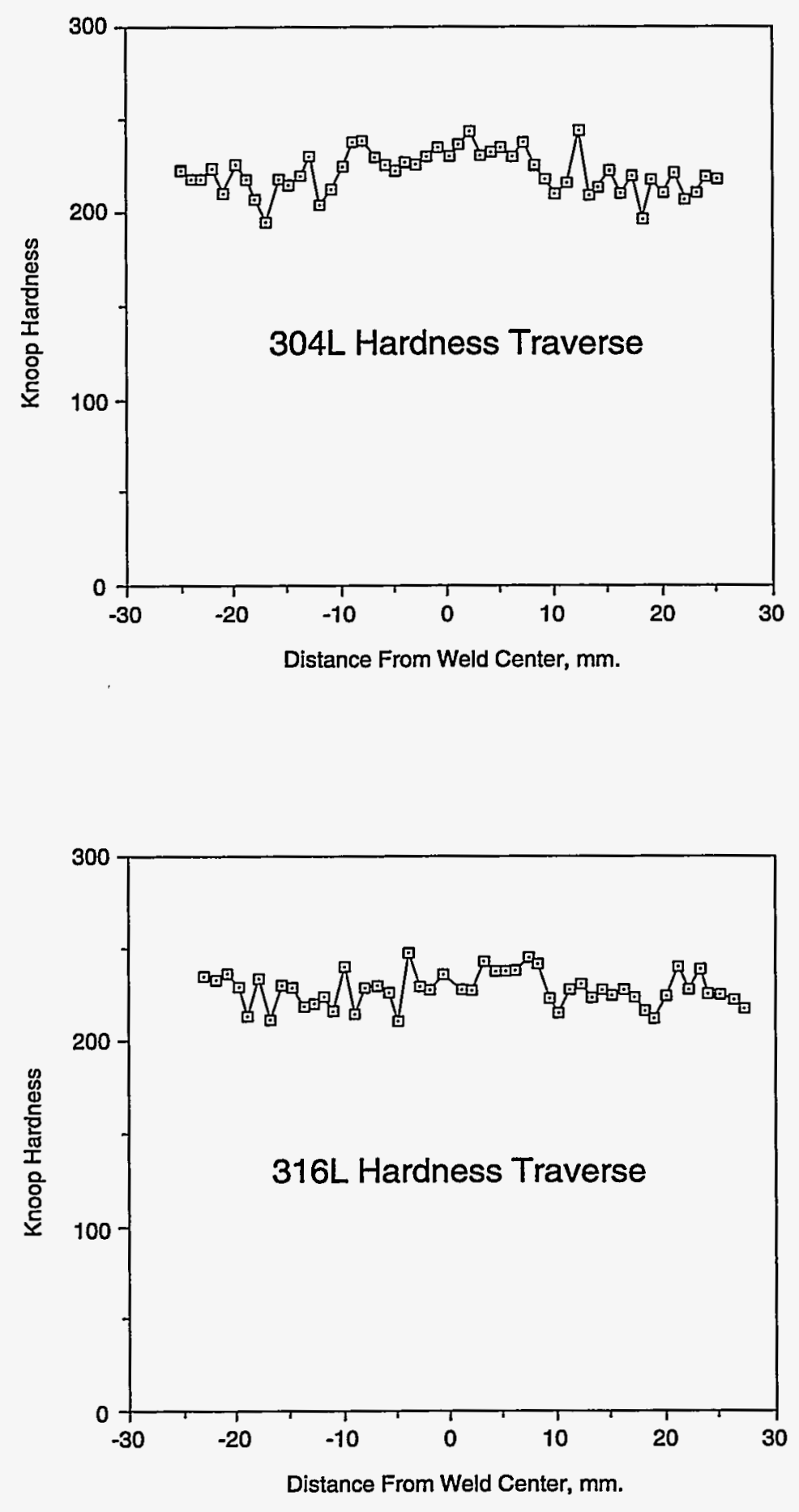

Figure 15. Plot of hardness data from Figures $10 \& 11$ shows that there is very little change in the hardness of the forged material due to the welding process. 
W. R. Kanne, Jr.

April 1996
WSRC-TR-96-0087

Page 24

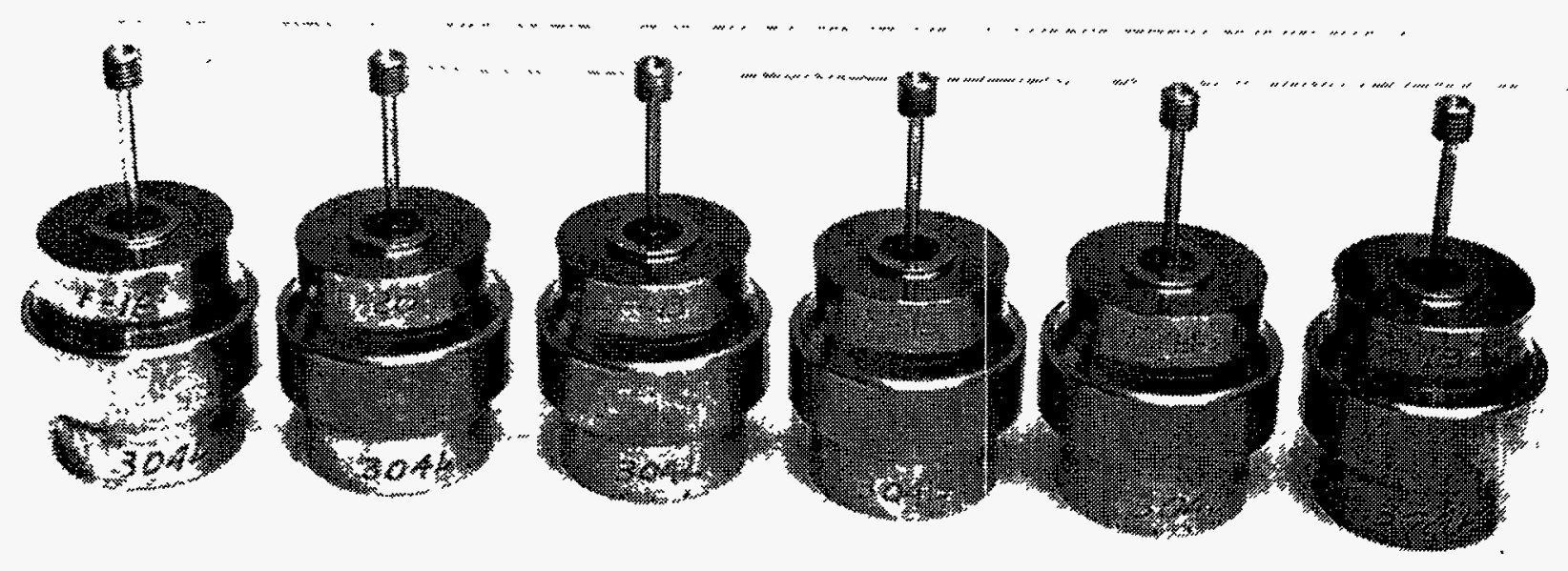

A. 304L vessels (0.5X, EE53651)
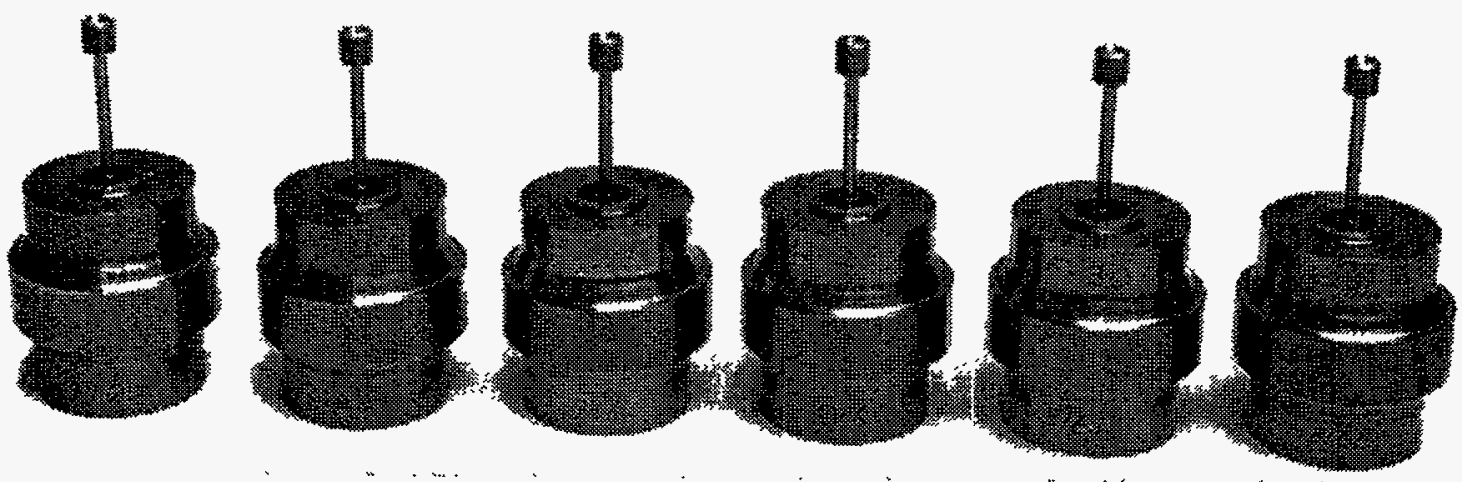

B. $316 \mathrm{~L}$ vessels (0.5X, EE53650)

Figure 16. Upset welded vessels from the sets prepared for storage tests. 